\title{
STORAGE TECHNIQUES OF CEMPAKA WASIAN (Magnolia tsiampaca (Miq.) Dandy) SEEDS
}

Arif Irawan ${ }^{* 1}$, Hanif N. Hidayah ${ }^{1}$, Iwanuddin² ${ }^{2}$ Julianus Kinho ${ }^{1}$, and Jafred E. Halawane ${ }^{1}$

${ }^{1}$ Enviroment and Forestry Research and Development Institute of Manado, Manado, Indonesia J1. Tugu Adipura Raya Kel. Kima Atas Kec. Mapanget Kota Manado, Sulawesi Utara 95259, Indonesia ${ }^{2}$ Wakatobi National Park, Jl. Dayanu Iksanuddin No.71 Kota Baubau-Sulawesi Tenggara 93724, Indonesia

Received: 2 February 2020, Revised: 22 October 2020, Accepted: 22 October 2020

STORAGE TECHNIQUES OF CEMPAKA WASIAN (Magnolia tsiampaca (Miq.) Dandy) SEEDS. Cempaka wasian is a type of woody tree which has a substantial historical value associated with the local culture of the Minahasan people. The improvement of cempaka wasian plantation is essential due to their enormous importance and usage. This study aims to discover the impacts of duration, storage room, and containers used for the appropriate storage of cempaka wasian seeds. The design used in this study is entirely randomized design organized with a factorial pattern which consists of three factors; 1) storage duration, 2) storage room and 3) storage containers. Duration of storage was 2, 3, 4, and 5 months; meanwhile, storage rooms comprised of refrigerators, chambers, and air-conditioned room. Moreover, storing containers consisted of calico cloth, aluminium foils, and plastic bags. The study finding indicates that the seeds of cempaka wasian could still germinate if stored for five months by using plastics bags inside refrigerators. A significant provision of seeds and suitable timing are closely related to the proper seed storage techniques.

Keywords: Seeds, cempaka wasian, storage duration, containers

TEKNIK PENYIMPANAN BENIH CEMPAKA WASLAN (Magnolia tsiampaca (Miq.) Dandy). Cempaka wasian merupakan jenis kayu yang memiliki nilai historis sangat erat dengan budaya masyarakat Minahasa. Pengembangan butan tanaman cempaka wasian perlu menjadi prioritas mengingat tingkat kebutuhannya cukup tinggi. Penyediaan benih dalam jumlah yang banyak dan pada waktu yang tepat sangat berkaitan dengan usaba metode penyimpanan benih yang sesuai. Penelitian ini bertujuan untuk mengetabui pengarub waktu, tempat, dan wadah penyimpanan yang sesuai untuk benib cempaka wasian. Rancangan yang digunakan dalam penelitian ini adalah acak. lengkeap yang disusun dengan pola factorial yang terdiri dari 3 (tiga) faktor, yaitu: 1) waktu penyimpanan, 2) ruang penyimpanan, dan 3) wadah penyimpanan. Waktu penyimpanan terdiri dari 4 faktor, yaitu 2; 3; 4; dan 5 bulan, tempat penyimpanan terdiri dari 3 faktor yaitu ruang kulkas; ruang kamar; dan ruang AC. Sedangkan wadah penyimpanan terdiri dari kain blacu; aluminium foil; dan plastik. Hasil penelitian menunjukean bahwa benih cempaka wasian masib dapat berkecambah optimal walaupun disimpan selama 5 (lima) bulan apabila menggunakan wadah simpan plastik dalam ruang kulkas.

Kata kunci: Benih, cempaka wasian, lama penyimpanan, wadah

*Corresponding author: arif_net23@yahoo.com 


\section{INTRODUCTION}

Cempaka wasian is a type of woody tree which has historical value closely associated with the local culture of the Minahasan people. Cempaka wasian timber has been utilized, even before the timber becomes the primary material for Woloan House (traditional house of Minahasa). Lumempouw (2014) stated that in the ceremonial process of building traditional houses in Tombulu (one of the local tribes of Minahasa), cempaka wasian is mostly collected from the forest and the timber is used as the core material. Additionally, the people of Minahasa embrace the psychological relationship with this wood because applying it as the primary house material is believed to provide a daily positive atmosphere.

Currently, cempaka timber supply is limited, and it is collected either from the natural or reserved forest for the traditional houses of Minahasa (Sasmuko, 2010). The development of cempaka wasian plantations must become a priority, due to their considerable consumption and it's culturally significant for the people of Minahasa. It necessitates the supply of a large quantity of cempaka wasian seeds with superior quality. Availability of seeds in large amounts is closely associated with the effort to the proper technique of storing seeds. During storing period, seeds experience a decline in germination value due to their physiological process as well as the surrounding environmental condition which is less optimal (Suita \& Darwo, 2015) (Nurisma, Agustiansyah \& Kamal, 2015).

Seeds of cempaka wasian are grouped as one of the seeds which cannot be stored for an extended period (Kinho \& Mahfudz, 2011). However, little information is recorded on the exact duration and method of storing these seeds. Irawan and Hidayah (2019) address that cempaka wasian seeds which have been stowed for a month in plastic bags were able to grow well with a germination rate of $>80 \%$. The experiment to identify longer conservation duration by applying applicable preservation method needs to be studied to complete available records. This study aims to discover the impact of appropriate storage duration, storage rooms, and containers for cempaka wasian seeds.

\section{MATERIAL AND METHOD}

The study aims to provide sufficient details of the research work to allow the method to be reproduced. This study was conducted from November 2018 to April 2019 at the Permanent Nursrey of BPDASHL (the Watershed and Protected Forest Management Unit) Tondano Kima Atas located at the office of Environment and Forestry Research and Development Centre, North Sulawesi Province. The material used in this research is the seeds of cempaka wasian, from Minahasa Selatan Regency. Meanwhile, the equipments used was sowing box for sowing seeds, sand, label, digital scale, oven, and stationaries.

\section{A. Methods}

The ripen seeds were extracted from the fruits then soaked overnight to remove the epidermis from the seeds. The seeds are stored according to the treatment. Duration of storage was 2, 3 , 4, and 5 months; meanwhile, storage room comprised of the refrigerator (temperature $4-10^{\circ} \mathrm{C}$; humidity $40-50 \%$ ), storage chambers with room temperature (temperature 26$30^{\circ} \mathrm{C}$; humidity $65-80 \%$ ), and rooms with air conditioners (temperature $18-21^{\circ} \mathrm{C}$; humidity 51-61\%). Further, storage containers consisted of calico cloth, aluminium foil, and plastic bags.

Every treatment comprises of three replications each with 50 seeds. Seed germination was observed for 40 days for each treatment. Seeds were not sown concurrently, but it is adjusted to the treatment of storage duration. The storage duration is grouped for the duration of 2, 3, and 4 months. The seeds were stored for two months, and then it is rejuvenated and observed for 40 days. The treatment of storage duration of 3 months, seeds were stored first for three months then it is rejuvenated and observed for 40 days. The treatment storage duration of 4 months, the seeds were stored for four months; then it was rejuvenated and observed for 40 days. The 
treatment of storage duration of five months, the seeds were stored for five months, then it was rejuvenated and observed for 40 days. This study employs a completely randomized design organized with a factorial pattern.

\section{B. Observed Parameters}

Experimental parameters were seed moisture content, germination rate, and germination speed. They were calculated using the following formula:

\section{Seed Moisture Content}

The water level in the seeds was measured using an oven temperature of $103 \pm 2^{\circ} \mathrm{C}$ for 17 hours. Each treatment consisted of 20 seeds. The water content is represented in the percentage of weight and calculated to the closest one decimal (ISTA, 2010) with the following formula:

Seed moisture content $(\%)=\frac{(M 2-M 3)}{(M 2-M 1)} \times 100 \%$

Where: M1 = containers' weight before oven (g); M2= containers' weight + seeds before oven $(\mathrm{g})$; M3 = containers weight + seeds after oven $(\mathrm{g})$

\section{Germination Rate}

The energy to grow is determined by the number of seeds which has sprouted. According to Sadjad,Muniarti, and Ilyas (1999) Siahaan (2017), the germination rate lays out the potential viability parameters with the formula:

Germination rate $(\%)=\sum \frac{\mathrm{KN}}{\mathrm{N}} \times 100 \%$ where: $\mathrm{KN}=$ number of normally germinated seeds; $\mathrm{N}$ $=$ number of sown seeds

\section{Germination Speed}

The calculated germination rate is the seeds that germinate from the first observation day to the last day. According to Widajati et al. (2012)) the rate of germination describes the vigour of parameters with the following formula:

Germination speed $(\%$ etmal $)=\sum_{\mathrm{i}=1}^{\mathrm{n}} \frac{(\mathrm{KN}) \mathrm{i}}{\mathrm{Wi}_{\mathrm{i}}}$

where: $\mathrm{i}=$ observation day; $(\mathrm{KN}) \mathrm{i}=$ normal germination on day i (\%); Wi= time (etmal) on day $\mathrm{i}$

\section{Analysis}

Data were analyzed by using analysis of variance (ANOVA). If the data is significantly different, further testing was carried out using Duncan's analysis.

\section{III.RESULT AND DISCUSSION}

Following the outcome of the analysis of variance, it can be said that the interaction between duration, storage room, and containers treatment offers absolute impact towards seed moisture content and the germination rate of cempaka wasian seeds (Table 1). Further tests to find out the best interaction treatment are shown in Table 2.

Table 1. Analysis of variances of the effect of duration, storage room, and containers treatment towards seed moisture content, the germination rate and germination speed of cempaka wasian seeds

\begin{tabular}{lcccc}
\hline \multirow{2}{*}{\multicolumn{1}{c}{ Source of variation }} & $\mathrm{db}$ & \multicolumn{3}{c}{ Mean of square } \\
\cline { 3 - 5 } & & $\begin{array}{c}\text { Seed moisture } \\
\text { content }\end{array}$ & $\begin{array}{c}\text { Germination } \\
\text { rate }\end{array}$ & $\begin{array}{c}\text { Germination } \\
\text { speed }\end{array}$ \\
\hline Duration & 3 & $43.23^{*}$ & $2,426,41^{*}$ & $3.09^{*}$ \\
Room & 2 & $23.40^{*}$ & $6,320.15^{*}$ & $11.05^{*}$ \\
Containers & 2 & $329.60^{*}$ & $12,176.70^{*}$ & $21.18^{*}$ \\
Duration x room & 6 & $2.44^{*}$ & $129.04^{*}$ & $0.19^{*}$ \\
Time x containers & 6 & $12.78^{*}$ & $840.26^{*}$ & $1.15^{*}$ \\
Room x containers & 4 & $72.97^{*}$ & $1,775.15^{*}$ & $3.28^{*}$ \\
Duration x room x containers & 12 & $8.21^{*}$ & $329.44^{*}$ & $0.69^{*}$ \\
Galat (Error) & 35 & 37.64 & $1,753.46$ & 0.08 \\
\hline
\end{tabular}

Remarks : $*$ significant at $95 \%$ confidence level 
Table 2. Duncan test on interaction effect of duration, room, and containers treatment towards seed moisture content, the germination rate and germination speed of cempaka wasian seeds

\begin{tabular}{|c|c|c|c|c|}
\hline No & Treatment & $\begin{array}{l}\text { Seed moisture } \\
\text { content }(\%)\end{array}$ & $\begin{array}{l}\text { Germination } \\
\text { rate }(\%)\end{array}$ & $\begin{array}{c}\text { Germination speed } \\
(\% \text { etmal })\end{array}$ \\
\hline 1. & Control & - & 88 & 4.67 \\
\hline 2. & 2 month $\mathrm{x}$ refrigerator $\mathrm{x}$ calico cloth & $9.35^{\mathrm{g}}$ & $0.00^{\mathrm{e}}$ & $0.00^{\mathrm{e}}$ \\
\hline 3. & 2 month $\mathrm{x}$ refrigerator $\mathrm{x}$ aluminium foil & $18.12^{\mathrm{c}}$ & $67.33^{a}$ & $2.57^{\mathrm{a}}$ \\
\hline 4. & 2 month $\mathrm{x}$ refrigerator $\mathrm{x}$ plastic bags & $20.56^{\mathrm{a}}$ & $72.00^{\mathrm{a}}$ & $2.63^{a}$ \\
\hline 5. & 2 month $\mathrm{x}$ chambers $\mathrm{x}$ calico cloth & $11.84^{\mathrm{f}}$ & $0.00^{\mathrm{e}}$ & $0.00^{\mathrm{e}}$ \\
\hline 6. & 2 month $\mathrm{x}$ chambers $\mathrm{x}$ aluminium foil & $13.57^{\mathrm{e}}$ & $14.00^{\mathrm{d}}$ & $0.45^{\mathrm{d}}$ \\
\hline 7. & 2 month $\mathrm{x}$ chambers $\mathrm{x}$ plastic bags & $15.84^{\mathrm{cd}}$ & $51.33^{\mathrm{b}}$ & $1.99^{\mathrm{b}}$ \\
\hline 8. & 2 month $\mathrm{x}$ air-conditioned room $\mathrm{x}$ calico cloth & $11.67^{\mathrm{f}}$ & $0.00^{\mathrm{e}}$ & $0.00^{\mathrm{e}}$ \\
\hline 9. & 2 month $\mathrm{x}$ air-conditioned room $\mathrm{x}$ aluminium foil & $12.58^{\mathrm{e}}$ & $6.00^{\mathrm{e}}$ & $1.19^{\mathrm{d}}$ \\
\hline 10. & 2 month $\mathrm{x}$ air-conditioned room $\mathrm{x}$ plastic bags & $16.85^{\mathrm{cd}}$ & $36.67^{\mathrm{c}}$ & $1.23^{\mathrm{e}}$ \\
\hline 11. & 3 month $\mathrm{x}$ refrigerator $\mathrm{x}$ calico cloth & $9.26^{\mathrm{g}}$ & $0.00^{\mathrm{e}}$ & $0.00^{\text {e }}$ \\
\hline 12. & 3 month $\mathrm{x}$ refrigerator $\mathrm{x}$ aluminium foil & $11.11^{\mathrm{f}}$ & $34.67^{\mathrm{c}}$ & $1.37^{\mathrm{c}}$ \\
\hline 13. & 3 month $\mathrm{x}$ refrigerator $\mathrm{x}$ plastic bags & $21.54^{\mathrm{a}}$ & $74.00^{\mathrm{a}}$ & $2.81^{\mathrm{a}}$ \\
\hline 14. & 3 month $x$ chambers $x$ calico cloth & $12.55^{\mathrm{ef}}$ & $0.00^{\mathrm{e}}$ & $0.00^{\mathrm{e}}$ \\
\hline 15. & 3 month $\mathrm{x}$ chambers $\mathrm{x}$ aluminium foil & $13.15^{\mathrm{e}}$ & $0.00^{\mathrm{e}}$ & $0.00^{\mathrm{e}}$ \\
\hline 16. & 3 month $x$ chambers $x$ plastic bags & 14.59 de & $33.33^{\mathrm{c}}$ & $1.37^{\mathrm{c}}$ \\
\hline 17. & 3 month $\mathrm{x}$ air-conditioned room $\mathrm{x}$ calico cloth & $10.39^{\mathrm{g}}$ & $0.00^{\mathrm{e}}$ & $0.00^{\mathrm{e}}$ \\
\hline 18. & 3 month $\mathrm{x}$ air-conditioned room $\mathrm{x}$ aluminium foil & $10.62^{\mathrm{f}}$ & $2.67^{\mathrm{e}}$ & $0.10^{\text {e }}$ \\
\hline 19. & 3 month $\mathrm{x}$ air-conditioned room $\mathrm{x}$ plastic bags & $18.74^{\mathrm{bc}}$ & $41.33^{c}$ & $1.89^{\mathrm{b}}$ \\
\hline 20. & 4 month $\mathrm{x}$ refrigerator $\mathrm{x}$ calico cloth & $8.88^{g}$ & $0.00^{\mathrm{e}}$ & $0.00^{\mathrm{e}}$ \\
\hline 21. & 4 month $\mathrm{x}$ refrigerator $\mathrm{x}$ aluminium foil & $9.77^{g}$ & $10.67^{\mathrm{d}}$ & $0.39^{\mathrm{d}}$ \\
\hline 22. & 4 month $\mathrm{x}$ refrigerator $\mathrm{x}$ plastic bags & 20.28 ab & $56.67^{\mathrm{b}}$ & $2.49^{a}$ \\
\hline 23. & 4 month $x$ chambers $x$ calico cloth & $10.48^{\mathrm{fg}}$ & $0.00^{\mathrm{e}}$ & $0.00^{\mathrm{e}}$ \\
\hline 24. & 4 month $\mathrm{x}$ chambers $\mathrm{x}$ aluminium foil & $11.27^{\mathrm{f}}$ & $0.00^{\mathrm{e}}$ & $0.00^{\mathrm{e}}$ \\
\hline 25. & 4 month $\mathrm{x}$ chambers $\mathrm{x}$ plastic & $11.80^{\mathrm{f}}$ & $0.00^{\mathrm{e}}$ & $0.00^{\mathrm{e}}$ \\
\hline 26. & 4 month $\mathrm{x}$ air-conditioned room $\mathrm{x}$ calico cloth & $9.42^{\mathrm{g}}$ & $0.00^{\mathrm{e}}$ & $0.00^{\mathrm{e}}$ \\
\hline 27. & 4 month $\mathrm{x}$ air-conditioned room $\mathrm{x}$ aluminium foil & $10.36^{\mathrm{g}}$ & $2.00^{\mathrm{e}}$ & $0.06^{\mathrm{e}}$ \\
\hline 28. & 4 month $\mathrm{x}$ air-conditioned room $\mathrm{x}$ plastic & $12.99^{\mathrm{e}}$ & $16.67^{\mathrm{d}}$ & $0.71^{\mathrm{d}}$ \\
\hline 29. & 5 month $\mathrm{x}$ refrigerator $\mathrm{x}$ calico cloth & $9.54^{\mathrm{g}}$ & $0.00^{\mathrm{e}}$ & $0.00^{\mathrm{e}}$ \\
\hline 30. & 5 month $\mathrm{x}$ refrigerator $\mathrm{x}$ aluminium foil & $9.55^{\mathrm{g}}$ & $10.00^{\mathrm{d}}$ & $0.41^{\mathrm{e}}$ \\
\hline 31. & 5 month $\mathrm{x}$ refrigerator $\mathrm{x}$ plastic bags & $18.90^{\mathrm{b}}$ & $52.00^{\mathrm{b}}$ & $2.52^{\mathrm{a}}$ \\
\hline 32. & 5 month $\mathrm{x}$ chambers $\mathrm{x}$ calico cloth & $12.41^{\mathrm{f}}$ & $0.00^{\mathrm{e}}$ & $0.00^{\mathrm{e}}$ \\
\hline 33. & 5 month $\mathrm{x}$ chambers $\mathrm{x}$ aluminium foil & $12.21^{\mathrm{f}}$ & $0.00^{\mathrm{e}}$ & $0.00^{\text {e }}$ \\
\hline 34. & 5 month $x$ chambers $x$ plastic bags & $12.60^{\mathrm{e}}$ & $0.00^{\mathrm{e}}$ & $0.00^{\mathrm{e}}$ \\
\hline 35. & 5 month $\mathrm{x}$ air-conditioned room $\mathrm{x}$ calico cloth & $10.91^{\mathrm{f}}$ & $0.00^{\text {e }}$ & $0.00^{\text {e }}$ \\
\hline 36. & 5 month $\mathrm{x}$ air-conditioned room $\mathrm{x}$ aluminium foil & $12.14^{\mathrm{f}}$ & $0.00^{\mathrm{e}}$ & $0.00^{\mathrm{e}}$ \\
\hline 37. & 5 month $\mathrm{x}$ air-conditioned room $\mathrm{x}$ plastic bags & $11.86^{\mathrm{f}}$ & $0.00^{\mathrm{e}}$ & $0.00^{\mathrm{e}}$ \\
\hline
\end{tabular}

Remarks: Values followed by the same letter are not significantly different at $95 \%$ confidence level

Based on Table 2, it can be concluded that the longer the seeds are stowed, the lower the moisture content and the germination energy are. The refrigerator can maintain moisture level and germination energy of cempaka wasian seeds; meanwhile, storage chambers with room temperature and the room with air conditioner decrease them. On the other hand, calico cloth negatively affects the water composite and germination energy of cempaka wasian seeds but will improve if stored in aluminium foil and plastic bags.

Preservation energy is influenced by various factors, such as condition and storage duration (Suszka et al., 2014). Duration is considered to have an actual impact on the percentage 
and the speed of seeds' sprouting (Siahaan, 2017; Solikin, 2016; Lestari, 2019). The growth values produced in this research points out that germination of cempaka wasian seeds can be sustained for five months using correct preservation method. Basically, the storage is an exertion to strive for seeds energy to develop optimally by minimalizing seeds' respiration (Suita \& Darwo, 2015).

The moisture level of cempaka wasian seeds retained in refrigerators using plastic bags possesses significantly similar values for 3 month conservation duration, whereas, longer storage duration (4 and 5 months) delivers significantly different - lower - values. These values are comparable with germination energy. Seeds which are preserved for 4 and 5 months inside refrigerators using plastic bags attain growth energy of $56.67 \%$ and $52 \%$ while for 2 and 3 months obtain $74 \%$ and $72 \%$. Anto and Jayaram (2010) address that seeds' moisture content positively correlated with the percentage of their germination, loss of seed moisture content will indirectly reduce the proportion of seed germination. Moreover, Mahjabin, Bilal, and Abidi (2015) explained that during the preservation process, water level and temperature are responsible for damaging seeds. Although conserving cempaka wasian seeds by cooling them at temperature $4^{\circ}-10^{\circ} \mathrm{C}$ using plastic bags obtained slighter germination energy parallel to storage duration, it is regarded more effective compared to other treatments which experience a dramatic decline in growing capability.

Zhao et al. (2017) stated that storage rooms with low temperatures and dry conditions have a good effect on maintaining the viability of seeds of most species of Hydrocharitaceae and Potamogetonaceae. Besides, reduction in developing ability due to insufficient water level was found in Pongamia pinnata (Aminah \& Syamsuwida, 2013), Rhizophora apiculate (Rohandi \& Widyani, 2010) (Nurisma, Agustiansyah \& Kamal, 2015) and Reutealisri sperma (Tresniawati, Murniati, \& Widajati, 2014).

Surya and Normasiwi (2019) stated that the speed of germination refers to the ability of the seeds to germinate in less than optimal environmental conditions. Lesilolo, Patty, and Tetty (2012) added that the speed of seed growth is a process of reactivation of seeds for optimum growth. Growth speed can be expressed as a measure of the duration it takes to achieve an etmal germination. Fast-growing sprouts indicated that the metabolic process is running optimally (Prasetya, Yulianah, Purnamaningsih, 2017, 2017). The speed of germination of cempaka wasian seeds is directly proportional to the germination rate (Tabel 2). Lestari (2019) state that the longer the seeds are stored, the speed of germination or seed growth power will decrease, so that the value of seed germination will also decrease. The value of seed germination is related to the speed of seed germination or seed growth capacity (Payung, Prihatiningtyas, \& Nisa, 2012).

Excellent quality and proper packaging can generate good maintenance room ecosystem for seeds as well as sustaining the water level; thus, the seeds can be preserved extensively (Lodong, Tambing, \& Adrianton, 2015). Plastic containers can endure the moisture content in the cempaka wasian seeds more productively in comparison to other storage containers because they are water-proof. Debtisari, Erawati, and Sugiyarto (2018) stated that preservation system using water-proof receptacle prevents excessive evaporation within the seeds during the conservation process, and seeds maintained in water-proof storages are capable of sustaining the germination viability and vigour of seeds. Furthermore, several seeds can be well upheld utilizing plastic such as cucumber seeds (Sumpena, 2012), rice seeds (Sari \& Faisal, 2017), and Manglietia glauce seeds (Suita \& Darwo, 2015). Plastic is a packaging substance which is resistant to humidity, pressure, and not fragile (Rahayu \& Widajati, 2007).

Furthermore, aluminium foil and calico cloth produce mediocre growth viability values compared to plastics. Cempaka wasian seeds conserved in calico cloth failed to sprout in all storage rooms. This calico cloth is suspected to increase respiration of cempaka wasian seeds; consequently, the moisture content decreases 
rapidly. Tuwu, Sutariati and Suaib (2012) indicated that calico cloth has the poorest effects towards the viability of sorghum seeds for the reason that packages made from this material are air translucent; as a result, the exchange between humidity and surrounding air can easily occur.

Additionally, Irawan and Iwanuddin (2019) reveal that calico cloth influences the deterioration water level in Pometia pinnata seeds. The seeds of cempaka wasian are assumed to have a higher level of respiration. Suryanto (2013) stated that calico cloth is a material that has large pores so that it is easy for air to pass. This condition causes the seeds to bind or release water into the air easily. This matter can be perceived through the utilization of calico cloth as a means of storage preserved in all three conservation rooms. Seeds preservation through calico textile inside a room with temperature $4^{\circ}-21^{\circ} \mathrm{C}$ (room with air conditioner and refrigerator) is generally competent to affect the seeds feasibility compared with no air conditioner room because of the temperature and humidity stability factors.

This situation is comparable to Manglieta glauca seeds retained in calico cloth inside room temperature $\left(25^{\circ}-30^{\circ} \mathrm{C}\right)$, which has lower germination capability than preservation inside rooms with air-conditioner and DCS (Suita \& Darwo, 2015). Furthermore, Zanzibar (2011) stated that points out that preserving Pinus merkusii seeds in room temperature accelerate the rate of seeds' decline. Nurisma, Agustiansyah and Kamal (2015) added that high storage temperature can trigger seeds respiration.

Refrigerators are considered as storage rooms which are proficient at offering optimal effects in storage techniques of cempaka wasian seeds. Seeds packed inside a plastic container in refrigerators significantly maintain the moisture level due to their abilities to avoid greater seed respirations. Purba, Sitepu, and Haryati (2013) explain that respiration occurs because enzyme activity in seeds is determined by moisture content and high relative humidity. Likewise, Taghfir, Anwar, and Kristanto (2018) express that refrigerator temperature conduces enzyme compound in the seeds become less active; hence the respiration process reduces. This deterioration process results in the declension activity of carbohydrate, protein, and seed fat degradation; therefore seed water level relatively unaltered. As Yuniarti and Nurhasybi (2015) expressed that longer drying and preservation will bring about changes in the viability (moisture level and germination energy) and biochemistry contents (fat, carbohydrate, and protein) of Michelia campaca seeds on various levels of drying and preserving method. Further, Yuniarti and Djaman (2015) claimed that low storage temperature reduces the speed of seed respiration; hence the period of seed preservation can be extended. Rahayu and Widajati (2007) presented that maintenance of seeds using plastics in refrigerator temperature can endure seeds' vigour of caisim up to 15 weeks. Similarly, Kolo and Tefa (2016) explain that in the cooler temperature respiration develop slowly; thus, the seed viability and vigour can be maintained extensively. Seed quality is sustained by controlling the moisture content during the preservation process inside refrigerators (Lestari, 2019).

Irawan and Hidayah (2019) suggest that if it is observed from the germination rapidity parameter, the stowing condition inside an air-conditioned room using plastic containers is regarded as the ideal circumstance to save cempaka wasian seeds for four weeks (germination rate $85.33 \%$ ). However, following the findings of this study, it can be said that the condition of the air-conditioned room is insufficient to provide a significant impact on germination energy when stored for $2-5$ months. This is due to plastic bags reserved in an air-conditioned chamber adequately supply the effect of optimal condition to cempaka wasian seeds to grow when kept up to 4 weeks. This can be examined from several seeds which have developed in containers when stored using this method. Therefore, in this particular condition, seeds undergo rapid growth. On the contrary, their germination energy will be minimized if held in reserve for more than four weeks because it has reached optimal condition for the seed to develop. 


\section{CONCLUSION}

The cempaka wasian seeds are included in the category of seeds that cannot be stored for a long period. Proper storage technique can extend shelf life and not affect its viability. Cempaka wasian seeds can be stored using a plastic container in the refrigerator. In such conditions, cempaka wasian seeds can survive their viability for up to 5 months (germination rate $52 \%$ ).

\section{ACKNOWLEDGEMENT}

Appreciation is conveyed to the of Enviroment and Forestry Research and Development Institute of Manado, Muchlis, S.Hut.T, MP, the Manager of Permanent Nursery of BPDASHL Tondano Kima Atas, Heri Prayitno, S.Hut, and seedbed officers Eky Kaeng and Opa (Agustinus Pangeke).

\section{REFERENCES}

Aminah, A., \& Syamsuwida, D. (2013). Penentuan karakteristik fisiologis benih kranji (Pongamia pinnata) berdasarkan nilai kadar air. Jurnal Penelitian Hutan Tanaman, 10(1), 1-6.

Anto, K. B., \& Jayaram, K. M. (2010). Effect of temperature treatment seed water content and viability of green pea (Pisum sativun L.) and soybean (Glycine $\max$ L. Merr.) seeds. International Journal of Botany, 6(2), 122-126.

Debtisari, H. E., Erawati, D. N., \& Sugiyarto. (2018). Pengaruh cara penyimpanan terhadap viabilitas benih kakao (Theobroma cacao l.) klon sulawesi 01. Prosiding Implementasi IPTEK Dalam Mewujudkan Ketahanan Pangan Nasional.

Irawan, A., \& Hidayah, H. N. (2019). Pengaruh kondisi dan periode simpan terhadap perkecambahan benih cempaka wasian (Magnolia tsiampaca (Miq.) Dandy). Jurnal Perbenihan Tanaman Hutan, 7(1), 55-65.

Irawan, A., \& Iwanuddin. (2019). Pengaruh waktu dan media simpan terhadap viabilitas benih matoa (Pometia pinnata) J . R . Forster \& J . G . Forster). Jurnal Pemuliaan Tanaman Hutan, 13(1), 53-60.

ISTA. (2010). International rules for seed testing (Edition 20). The International Seed Testing
Association.

Kinho, J., \& Mahfudz. (2011). Prospek pengembangan cempaka di Sulawesi Utara. Balai Penelitian Kehutanan Manado, Manado.

Kolo, E., \& Tefa, A. (2016). Pengaruh kondisi simpan terhadap viabilitas dan vigor benih tomat (Lycopersicum esculentum Mill). Savana Cendana, 1(3), 112-115. doi://10.32938/ sc.v1i03.57.

Lesilolo, M. K., Patty, J., \& Tetty, N. (2012). Penggunaan desikan abu dan lama simpan terhadap kualitas benih jagung (Zea mays L.) pada penyimpanan ruang terbuka. Agrologia, 1(1), 51-59.

Lestari, D. A. (2019). Teknik penyimpanan benih rekalsitran: Mesoa ferra $L$ dan Swwinglea glutinosa (Blaneo) Merr. Jurnal Perbeniban Tanaman Hutan, 7(1), 31-44. doi://10.20886/ bptpth.2019.7.1.31-44.

Lodong, O., Tambing, Y., \& Adrianton. (2015). Peranan kemasan dan media simpan terhadap ketahanan viabilitas dan vigor benih nangka (Artocarpus heterophyllus Lamk) kultivar Tulo-5 selama penyimpanan. Agrotekbis, 3(3), 303-315.

Lumempouw, F. (2014). Proses pembuatan rumah menurut adat di daerah tombulu. Kajian komunitas adat dan budaya bahari. Accessed from http://repo.unsrat.ac.id/471/1/ proses_pembuatan_rumah_menurut_adat_ di_daerah_tombulu.pdf on 9 February 2020.

Mahjabin, Bilal, S., \& Abidi, A. B. (2015). Physiological and biochemical changes during seed deterioration: A review. International Journal of Recent Scientific Research, 6(4), 3416-3422.

Nurisma, I., Agustiansyah \& Kamal, M. (2015). Pengaruh jenis kemasan dan suhu ruang simpan terhadap viabilitas benih sorgum (Sorghum bicolor [L.] Moench). Jurnal Penelitian Pertanian Terapan, 15(3), 183-190.

Payung, D., Prihatiningtyas, E., \& Nisa, S. H. (2012). Uji daya kecambah benih sengon (Paraserianthes falcataria (L.) Nielsen) di green house. Jurnal Hutan Tropis, 13(2), 132138.

Prasetya, W., Yulianah, I., \& Purnamaningsih, L. (2017). The influence of extraction technique and variety towards viability tomato (Lycopersicum esculentum $L$.) seeds. Jurnal Produksi Tanaman, 5(2), 257-264. 
Purba, H. W. S., Sitepu, F. E., \& Haryati. (2013). Viabilitas benih rosela (Hibiscus sabdariffa L.) pada berbagai kadar air awal dan kemasan benih. Jurnal Online Agroekoteknologi, 1(2), 318-326.

Rahayu, E., \& Widajati, E. (2007). Pengaruh kemasan, kondisi ruang simpan dan periode simpan terhadap viabilitas benih Caisin (Brassica chinensis L.). Buletin Agron, 35(3), 191-196. doi://10.24831/jai.v35i3.1330.

Rohandi, A., \& Widyani, N. (2010). Dampak penurunan kadar air terhadap respon fisiologis dan biokimia propagul Rhizopora apiculata BL. Jurnal Penlitian Hutan Tanaman, 7(4), 167-179.

Sadjad, S., Muniarti, E., \& Ilyas, S. (1999). Parameter pengujian vigor benih komparatif ke simulatif. PT. Grasindo.

Sari, W., \& Faisal, M. F. (2017). Pengaruh media penyimpanan benih terhadap viabilitas dan vigor benih padi pandanwangi. Agroscience, 7(2), 300-310.

Sasmuko, S. A. (2010). Karakteristik kayu lokal untuk rumah woloan di provinsi Sulawesi Utara. Jurnal Penelitian Hasil Hutan, 28(3), 278-290.

Siahaan, F. A. (2017). Pengaruh kondisi dan periode simpan terhadap perkecambahan benih kesambi (Schleichera oleosa (Lour.) Merr). Jurnal Perbeniban Tanaman Hutan, 5(1), 1-11.

Solikin. (2016). Pengaruh lama penyimpanan terhadap perkecambahan biji sambiloto (Andrographis paniculata (Burm.f.) Wallich ex Nees). Berita Biologi, 15(2), 201-206. doi://10.1017/CBO9781107415324.004.

Suita, E., \& Darwo. (2015). Teknik penyimpanan benih manglid (Maglieta glauca BL). Jurnal Penelitian Hutan Tanaman, 12(2), 129-137.

Sumpena, U. (2012). Pengaruh kemasan dan waktu penyimpanan terhadap kemampuan berkecambah benih mentimun. Mediaagroagro, $8(1), 18-25$.

Surya, M. I., \& Normasiwi, S. (2019). Kajian pengusangan cepat dan penyimpanan biji terhadap perkecambahan Anaphalis longifolia (Blume) Blume ex.DC. A. Jurnal Ilmu Kebutanan, 13, 48-55.

Suryanto, H. (2013). Pengaruh beberapa perlakuan penyimpanan terhadap perkecambahan benih suren. Jurnal Penelitian Kehutanan Wallacea, 2(1), 26-40.
Suszka, J., Plitta, B. P., Michalak, M., BujarskaBorkowska, B., Tylkowski, T., \& Chmielarz, P. (2014). Optimal seed water content and storage temperature for preservation of Populus nigra L. germplasm. Annals of Forest Science, 71(5), 543-549. doi://10.1007/ s13595-014-0368-2.

Taghfir, D. B., Anwar, S., \& Kristanto, B. A. (2018). Kualitas benih dan pertumbuhan bibit cabai (Capsicum frutescens 1.) pada perlakuan suhu dan wadah penyimpanan yang berbeda. Journal of Agro Complex, 2(2), 137. doi: //10.14710/joac.2.2.137-147.

Tresniawati, C., Murniati, E., \& Widajati, E. (2014). Perubahan fisik, fisiologi dan biokimia selama pemasakan benih dan studi rekalsitransi benih kemiri sunan. Jurnal Agronomi Indonesia, 42(1), 74-79. doi: //10.24831/jai.v42i1.8157.

Tuwu, E. R., Sutariati, G. A. K., \& Suaib. (2012). Pengaruh kadar air benih dan jenis kemasan terhadap vigor benih sorgum (Sorgum bicolor ( $L$ ) Moench) dalam enam bulan masa simpan. Berkala Penelitian Agronomi, 1(2), 184-193.

Widajati, Murniati, E., Palupi, E. R., Kartika, T., Suhartanto, M. R., \& Qadir. (2012). Dasar ilmu dan teknologi benib. Bogor: IPB Press.

Yuniarti, N, \& Djaman,D. (2015). Teknik pengemasan yang tepat untukmempertahankan viabilitas benih bakau (Rhizophora apiculata) selama penyimpanan. Prosiding Seminar Nasional Masyarakat Biodiversity Indonesia, 1438-1441.

Yuniarti, N., \& Nurhasybi. (2015). Perubahan viabilitas dan biokimia benih bambang lanang (Michelia champaca Linn.) pada berbagai tingkat pengeringan dan metode penyimpanan. Jurnal Perbeniban Tanaman Hutan, 3(1), 36-48.

Zanzibar, M. (2011). Efektifitas perlakuan priming dan metode pendugaan mutu fisiologis secara cepat pada benih tusam (Pinus merkusii Jungh et de Vriese). Jurnal Standardisasi, 13(2), 90-97. doi://10.31153/js.v13i2.129.

Zhao, S., Zhang, R., Liu, Y., Yin, L., Wang, C., \& Li, W. (2017). The effect of storage condition on seed germination of six Hydrocharitaceae and Potamogetonaceae species. Aquatic Botany, 143(September), 4953. doi://10.1016/j.aquabot.2017.09.005. 